\title{
PENERAPAN ALGORITMA ITERATIVE DICHOTOMISER THREE (ID3) DALAM MENDIAGNOSA KESEHATAN KEHAMILAN
}

\author{
Hikmatulloh' ${ }^{1}$, Ami Rahmawati2 ${ }^{2}$ Dede Wintana3 ${ }^{3}$ Diah Ayu Ambarsari4, \\ STMIK Nusa Mandiri Jakarta \\ Jl. Kramat Raya No. 18 Kelurahan Kwitang Kec. Senen \\ Telp. (021) 31908575 Fax. (021) 31908565 \\ hikmatul0808@bsi.ac.id¹, amirahma0304@bsi.ac.id², dedewint1311@bsi.ac.id³, \\ diahayua1508@bsi.ac.id ${ }^{4}$
}

\begin{abstract}
Pregnancy is a natural process in a woman, pregnancy usually has a period of 9 months 1 week divided into 3 trimesters. The discussion of this study on pregnancy focused on determining the health of pregnant women with the help of data mining processing on classification methods, data processing is done by the iterative dichotomized three (ID3) algorithm, there are 14 parameters measured in processing the dataset including stages of pregnancy, nausea and vomiting, flatulence, heartburn, sensitivity to smell, vaginal blood, urination, urination, blood pressure, pulse, body temperature and dehydration, tightness in the uterus, odor of vaginal discharge, color of vaginal discharge, and the result parameter as the label. In its calculation algorithm, ID3 produces an accuracy of $80.33 \%$. The application of the ID3 algorithm in diagnosing pregnancy health is expected to produce useful information, the results of this study are implemented in an Android-based mobile application.
\end{abstract}

Keywords: fregnancy, ID3, android.

\begin{abstract}
Abstrak
Kehamilan adalah sebuah proses alamiah pada seorang perempuan, masa kehamilan biasanya memiliki rentang waktu 9 bulan 1 minggu yang dibagi menjadi 3 trimester. Pembahasan penelitian ini mengenai kehamilan yang difokuskan pada penentuan kesehatan pada ibu hamil dengan bantuan pengolahan data mining pada metode klasifikasi, pengolahan data dilakukan dengan algoritma iterative dichotomiser three (ID3), ada 14 parameter yang di ukur dalam pengolahan dataset, diantaranya tahapan kehamilan, mual dan muntah, perut kembung, nyeri ulu hati, senssitif terhadap bau, darah pada vagina, sakit buang air kecil, jumlah buang air kecil, tekanan darah, denyut nadi, suhu tubuh dan dehidrasi, kencang pada rahim, bau cairan dari vagina, warna cairan dari vagina, dan parameter hasil sebagi label. Dalam perhitungannya algoritma ID3 menghasilkan akurasi sebesar 80,33\%. Penerapan algoritma ID3 dalam mendiagnosa kesehatan kehamilan ini diharapkan menghasilkan informasi yang bermanfaat, maka hasil penelitian ini di implementasikan dalam aplikasi mobile berbasis android.
\end{abstract}

Kata kunci: kehamilan, ID3, android. 


\section{PENDAHULUAN}

\subsection{Latar Belakang}

Kehamilan merupakan suatu proses kehidupan yang dialami oleh wanita, menurut Federasi Obstetri Ginekologi Internasional [1]. Kehamilan didefinisikan sebagai fertilisasi atau penyatuan dari spermatozoa dan ovum, dilanjutkan dengan nidasi atau implantasi. Lama kehamilan dibagi menjadi tiga triwulan yaitu 280 hari (40 minggu atau 9 bulan 7 hari)".

Angka Kematian lbu (AKl) merupakan indikator pembangunan kesehatan dan indikator pemenuhan hak reproduksi perempuan serta kualitas pemanfaatan kesehatan secara umum. Salah satu penyebab tingginya angka kematian ibu di Indonesia adalah keterbatasan pengetahuan masyarakat tentang perawatan kehamilan [2]. Upaya untuk menurunkan angka kematian dan kesakitan ibu adalah dengan memperluas cakupan pelayanan ANC (Antenatal Care) melalui pemeriksaan kehamilan. Pemeriksaan kehamilan merupakan salah satu intervensi kesehatan yang efektif untuk mencegah kesakitan dan kematian ibu [3].

Tidak semua wanita memiliki proses kehamilan yang lancar. Beragamnya karakteristik dan sulitya untuk membedakan gejala pada kesehatan kehamilan yang terjadi sering menimbulkan kecemasan pada ibu hamil. Ketika merasa cemas, individu merasa tidak nyaman atau takut atau mungkin memiliki firasat akan ditimpa malapetaka padahal ia tidak mengerti mengapa emosi yang mengancam tersebut terjadi [4]. Rasa cemas tersebut sering menimbulkan pengaruh negatif kepada ibu hamil. Hal ini terjadi karena proses dan resiko saat hamil dapat menimbulkan reaksi psikologis seperti stress, dan apabila tidak dikelola dengan baik maka akan berakibat negatif bagi wanita hamil secara fisik maupun mental.

Oleh karena adanya keberagaman karakteristik seperti periode kehamilan dan keluhan dalam normalitas kehamilan maka penulis tertarik melakukan penelitian lebih lanjut dalam mendiagnosa kesehatan kehamilan. Dalam mendiagnosa kesehatan kehamilan diperlukannya klasifikasi antara kehamilan yang sehat dan tidak sehat. Kinerja pengolahan algoritma sangat diperlukan untuk menentukan pengklasifikasian tersebut, maka dari dalam penelitian ini akan menggunakan metode klasifikasi.

Beberapa metode klasifikasi telah digunakan dalam memprediksi sebuah masalah, dan dalam penelitian diagnose kehamilan ini akan menggunakan algoritma ID3, algoritma ini mempunyai struktur flowchart yang mempunyai tree (pohon), dimana setiap simpul internal menandakan suatu tes pada atribut, setiap cabang merepresentasikan hasil tes, dan simpul daun mempresentasikan kelas atau distribusi kelas [5]. Sehingga setelah di implementasikan akan menghasilkan sebuah informasi yang akan membantu masyarakat khususnya ibu hamil dalam menilai kesehatan kehamilannya. 


\subsection{Penelitian Terkait}

Penelitiaan ini terinspirasi dari penelitian sebelumnya yang dilakukan oleh Diah Damayanti, Ratih Sari Wardani, dan Nuke Dewi Indrawati tahun 20 dengan judul STUDI deskriptif tingkat pengetahuan tentang ketidaknyamanan selama kehamilan pada ibu hamil trimester pertama di bpm ny.a pundenarum demak. Dalam penelitiannya. Hasil penelitian yang telah di lakukan pada ibu hamil mengenai 80 ketidaknyamanan selama kehamilan trimester pertama pada bulan Juli- Agustus 2010, di ambil kesimpulan bahwa mayoritas responden mempunyai pengetahuan baik tentang ketidaknyamanan kehamilan sebesar 37 responden $(80,4 \%)$ dan kategori kurang sebesar 2 responden $(4,3 \%)$ [3].

Selanjutnya penelitian yang dilakukan oleh Yusuf Elmande dan Prabowo Pudjo Widodo pada tahun 2012 yang berjudul "Pemilihan Criteria Splitting Dalam Algoritma Iterative Dichotomiser 3 (ID3) Untuk Penentuan Kualitas Beras : Studi Kasus Pada Perum Bulog Divre Lampung". Dalam penelitian ini dilakukan pembuatan model menggunakan algoritma ID3 menggunakan data kualitas beras yang diterima maupun ditolak pada Perum Bulog Divre Lampung. Dan dapat disimpulkan bahwa, metode ID3 pada splitting gain ratio dapat menghasilkan decision tree yang akurat dan juga merupakan metode yang sangat baik dalam pengklasifikasian data, dengan demikian algoritma ID3 pada splitting gain ratio juga dapat memberikan pemecahan untuk sebuah permasalahan [5].

Berdasarka beberapa jurnal yang telah penulis baca diantaranya mengenai ketidaknyamanan dalam masa kehamilan dan penggunaan algoritma Iterative Dichotomiser 3 (ID3) dalam penyelesaian masalah, maka penulis mendapatkan celah untuk melakukan penelitian tentang kehamilan yang akan membahas mengenai kesehatan kehamilan, dalam penelitian ini penulis akan menggunakan bantuan algotima Iterative Dichotomiser 3 (ID3) dengan pengolahan nya menggunakan aplikasi rapidminer serta penjelasan secara manualnya, setelah pengolahan algoritma selesai penulis akan mengimplementasikannya pada aplikasi mobile berbasis android agar dapat lebih mudah di akses oleh penggunanya.

\section{METODOLOGI PENELITIAN}

Pengumpulan data yang digunakan pada penelitian ini menggunakan data primer yang didapatkan dari puskesmas Sukaraja Sukabumi. Dan berdasarkan hasil pengumpulan data dari puskesmas Sukaraja Sukabumi maka dapat diambil kesimpulan mengenai sample data untuk diagnose kesehatan kehamilan. Penelitian ini menggunakan sample data sebanyak 91 data, 47 data menunjukan kehamilan yang sehat dan 44 data menunjukan kehamilan yang tidak sehat. 


\subsection{Landasan Penelitian}

\subsubsection{Data Mining}

Sebelum kita mengenal data mining alangkah baiknya kita harus tau terlebih dahulu mengenal data werehouse, karena antara data mining memiliki hubungan yang erat dengan data werehouse. Data werehouse adalah kumpulan data dari berbagai sumber yang ditempatkan menjadi satu dalam tempat penyimpanan berukuran besar lalu diproses menjadi bentuk penyimpanan multi-dimensional dan didesain untuk querying dan reporting.

Bisa kita simpulkan bahwa data werehouse merupakan suatu sistem yang mengkonsolidasikan data secara periodic dari sistem-sistem yang ada (OLTP) kedalam suatu penyimpanan dimensional. Pada umumya, data werehouse menyimpan data histori beberapa tahun dan akan dilakukan query untuk keerluan bussines intelligence atau aktifitas analisis lainnya. Sebagai tambahan informasi, perkembangan saat ini data werehouse digunakan sebagai sumber data untuk bussines intelligence (BI), penyempurnaan CRM (Customer Relationship Management) ataupun data mining (DM).

Sedangkan Data mining disebut knowledge discovery karena merupakan bidang yang berupaya untuk menemukan informasi yang punya arti dan berguna dari jumlah data yang besar. Data mining merupakan suatu proses yang interaktif atau terotomatisasi untuk menemukan pola (pattern) data tersebut dan memprediksi kelakuan (trend) dimasa mendatang berdasarkan pola data tersebut.

Dari sini bisa kita simpulkan bahwa data mining menambil data yang berasak dari werehouse, untuk kemudian nanti dilakukan pengolahan, untuk menghasilkan sebuah pola yang baik dan menguntungkan.

\subsubsection{Algoritma Iterative Dichotomiser Three (ID3)}

Iterative Dichotomizes 3 (ID3) adalah algoritma decision tree learning (algoritma pembelajaran pohon keputusan) yang paling dasar. Algoritma ini melakukan pencarian secara rakus /menyeluruh (greedy) pada semua kemungkinan pohon keputusan. Salah satu algoritma induksi pohon keputusan yaitu ID3 (Iterative Dichotomizes 3). ID3 dikembangkan oleh J. Ross Quinlan. Algoritma ID3 dapat diimplementasikan menggunakan fungsi rekursif (fungsi yang memanggil dirinya sendiri). Algoritma ID3 berusaha membangun decision tree (pohon keputusan) secara top-down (dari atas ke bawah), mulai dengan pertanyaan : "atribut mana yang pertama kali harus dicek dan diletakkan pada root?" pertanyaan ini dijawab dengan mengevaluasi semua atribut yang ada dengan menggunakan suatu ukuran statistic (yang banyak digunakan adalah information gain) untuk mengukur efektivitas suatu atribut dalam mengklasifikasikan kumpulan sampel data [6].

Secara ringkas, cara kerja Algoritma ID3 dapat digambarkan sebagai berikut. Pemilihan atribut dengan menggunakan Information Gain [5]. 
a. Pilih atribut dimana nilai information gainnya terbesar.

b. Buat simpul yang berisi atribut tersebut.

c. Proses perhitungan information gain akan terus dilaksanakan sampai semua data telah termasuk dalam kelas yang sama. Atribut yang telah dipilih tidak diikutkan lagi dalam perhitungan nilai information gain.

Pemilihan atribut pada ID3 dilakukan dengan properti statistik, yang disebut dengan information gain. Gain mengukur seberapa baik suatu atribut memisahkan training example ke dalam kelas target. Atribut dengan informasi tertinggi akan dipilih. Dengan tujuan untuk mendefinisikan gain, pertama-tama digunakanlah ide dari teori informasi yang disebut entropi. Entropi mengukur jumlah dari informasi yang ada pada atribut dengan rumus :

$$
\text { Entropy }(S)=-P_{+} \log _{2} P_{+}-P_{-} \log _{2} P_{-}
$$

Berdasarkan rumus di atas, $\mathrm{P}+$ adalah probabilitas sampel $\mathrm{S}$ yang mempunyai class positif. $\mathrm{P}+$ dihitung dengan membagi jumlah sampel positif $(\mathrm{S}+)$ dengan jumlah sampel keseluruhan $(\mathrm{S})$ sehingga. $\mathrm{P}_{+}=\mathrm{S}_{+} / \mathrm{S}$.

P- adalah probabilitas sampel S yang mempunyai class negatif. P- dihitung dengan membagi jumlah sampel negatif (S-) dengan jumlah sampel keseluruhan (S) sehingga $\mathrm{P}_{-}=\mathrm{S}_{-} / \mathrm{S}$. Bagian daun dari sebuah decision tree, idealnya hanya terdiri dari data e-mail Spam dan e-mail non-Spam. Dengan kata lain bagian daun adalah sampel murni, jadi ketika membagi sebuah sampel, sisa sampel harus lebih murni dibandingkan simpul sebelumnya. Oleh karena itu nilai entropy harus dikurangi. Pada algoritma ID3 pengurangan entropy disebut dengan informasi gain. Pembagian sampel S terhadap atribut A dapat dihitung information gain dengan rumus:

$$
\operatorname{Gain}(S, A)=\operatorname{Entropy}(S)-\sum_{\text {veniati } ;} \frac{\left|S_{\mathrm{v}}\right|}{|S|} \operatorname{Entropy}\left(S_{\mathrm{z}}\right)
$$

Value A adalah semua nilai yang mungkin dari atribut A, dan Sv adalah subset dari $S$ dimana A mempunyai nilai c. bagian pertama pada rumus adalah entropy total $S$ dan bagian kedua adalah entropy sesudah dilakukan pemisahan data berdasarkan atribut $\mathrm{A}$.

\subsubsection{RapidMiner}

RapidMiner merupakan perangkat lunak yang bersifat open source. RapidMiner merupakan solusi untuk melakukan analisis terhadap data mining, text mining dan analisis prediksi. RapidMiner merupakan perangkat lunak yang berdiri sendiri untuk analisis data dan sebagai mesin data mining yang diintegrasikan pada produknya sendiri [7].

RapidMiner adalah sebuah lingkungan machine learning data mining, text mining dan predictive analytics [8]. Rapidminer adalah koleksi dari algoritma 
learning machine yang digunakan untuk tugas-tugas data mining. Rapidminer berisi tool untuk data pre-processing, klasifikasi, regresi, clustering, rule association, dan memvisualisasikan data tersebut menjadi mudah untuk dapat dipahami. Pada bagian ini, hasil eksperimen dianalisis untuk mengevaluasi kinerja algoritma data mining yang diusulkan [9].

\subsubsection{Kehamilan}

Kehamilan adalah serangkaian proses yang dialami oleh wanita yang diawali dengan pertemuan antara sel telur dan sel sperma di dalam indung telur (ovarium) wanita, lalu berlanjut ke pembentukan zigot, perlekatan atau menempel di dinding rahim, pembentukan plasenta, dan pertumbuhan serta perkembangan hasil konsepsi sampai cukup waktu (aterm). Normalitas kehamilan adalah kehamilan dimana ibu hamil dalam keadaan sehat, tidak ada riwayat obstetric buruk, ukuran uterus sama/sesuai usia kehamilan serta hasil pemeriksaan fisik dan laboratorium normal.

\subsection{Objek Penelitian}

Masa kehamilan merupakan masa dimana tubuh seorang ibu hamil mengalami perubahan fisik, dan perubahan psikologis akibat peningkatan hormon kehamilan. Sebagian ibu hamil mengalami rasa khawatir, was-was, gelisah, takut dan cemas dalam menghadapi kehamilannya. Perasaan - perasaan yang muncul antara lain berkaitan dengan keadaan janin yang dikandung, ketakutan dan kecemasan dalam menghadapi persalinannya, serta perubahan fisik dan psikis yang terjadi [10].

Objek penelitian ini yakni untuk mengetahui sehat tidaknya kehamilan yang terjadi pada seorang ibu hamil, sehingga akan mengurangi tingkat kecemasan maupun kekhawatiran yang dialami oleh ibu hamil tersebut, karena jika tidak diketahui akan sering terjadi gangguan psikologis yang beresiko buruk pada ibu itu sendiri maupun kepada janinnya.

Waktu penelitian dilaksanakan selama bulan November sampai dengan Desember 2018 di Puskesmas Sukaraja Sukabumi dengan mengambil sample data sebanyak 91 data ibu hamil dalam kurun kehamilan trimester 1 sampai trimester 3, dari 91 data sample tersebut diketahui sebanyak 47 data sample menunjukan kehamilan yang sehat dan 44 data sample menunjukan kehamilan yang tidak sehat.

\section{HASIL DAN PEMBAHASAN}

Berdasarkan perhitungan menggunakan algoritma ID3 yang dilakukan menggunakan aplikasi rapidminer dan perhitungan secara manual, maka dari perhitungan tersebut dapat diketahui apakah suatu kehamilan tersebut sehat atau tidak sehat, berikut adalah hasil dari penelitian yang telah dilakukan: 


\subsection{Hasil Implementasi Menggunakan Aplikasi Rapidminer}

Rancangan proses klasifikasi data proses menentukan kesehatan pada ibu hamil menggunakan aplikasi rapidminer ditunjukan pada gambar 1 , dan di eksekusi untuk menghasilkan sebuah pohon keputusan untuk mengetahui hasil klasifikasi dalam menentukan kesehatan pada ibu hamil berdasarkan atribut yang telah ditentukan ditunjukan pada gambar 2 .

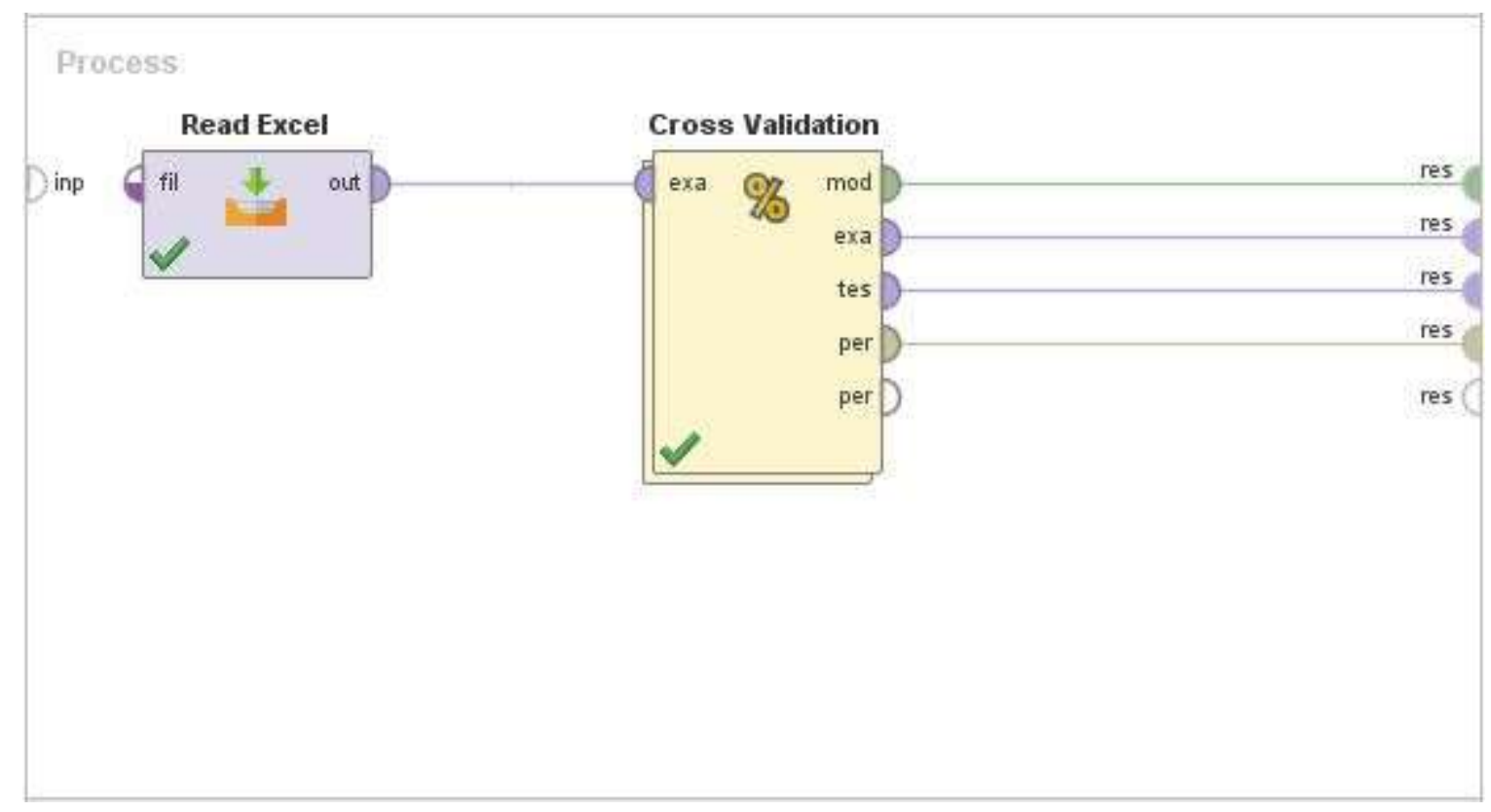

Gambar 1 Rancangan Alur Proses

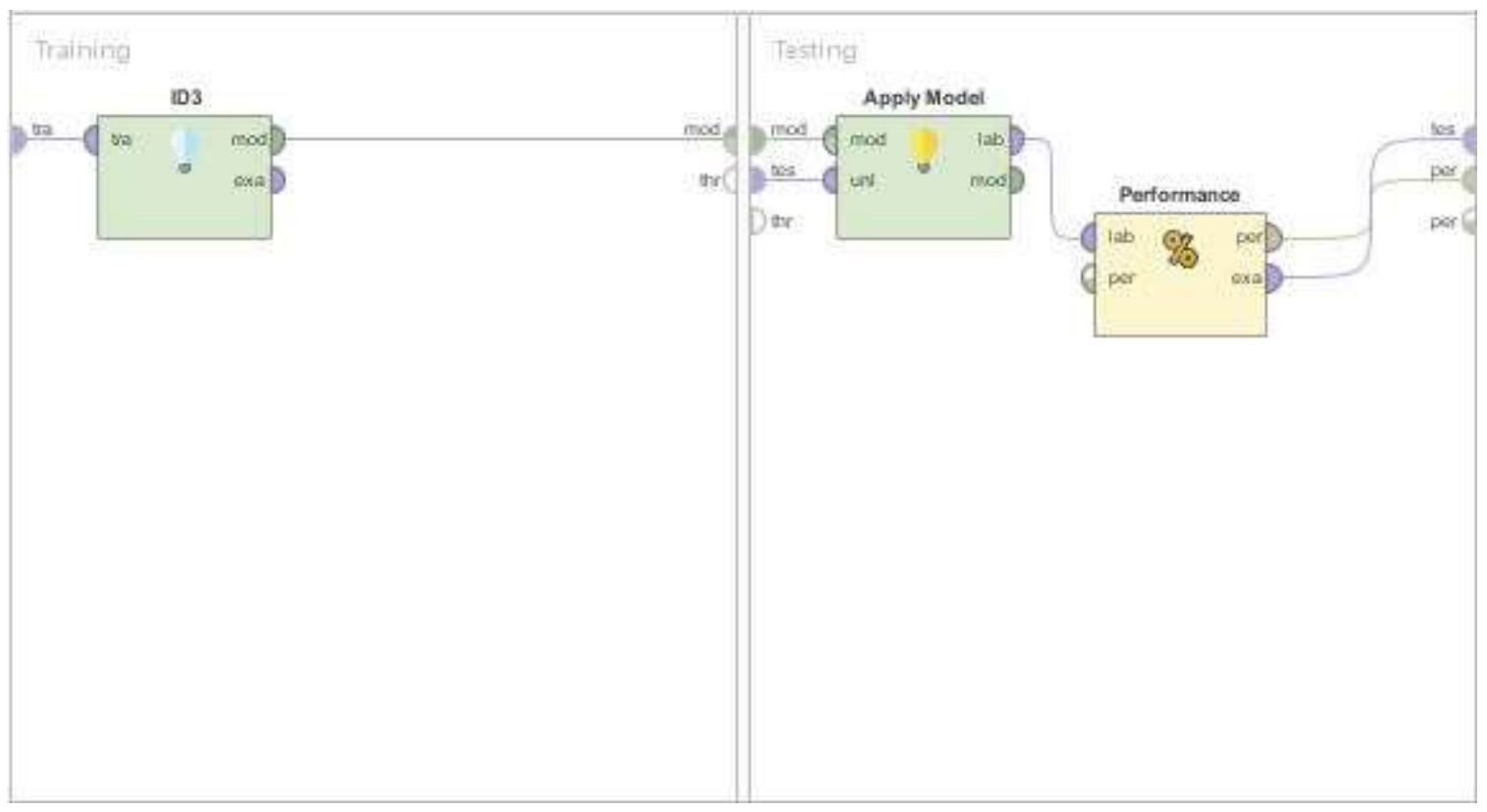

Gambar 2 Rancangan Cross Validation 


\section{PerformanceVector}

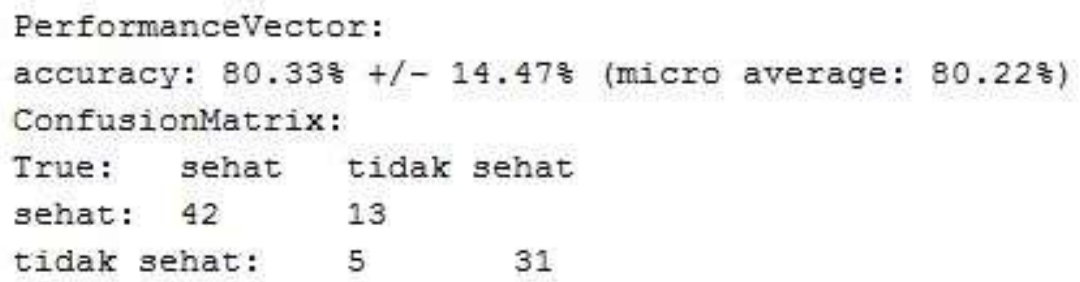

Gambar 3 Performance Vektor

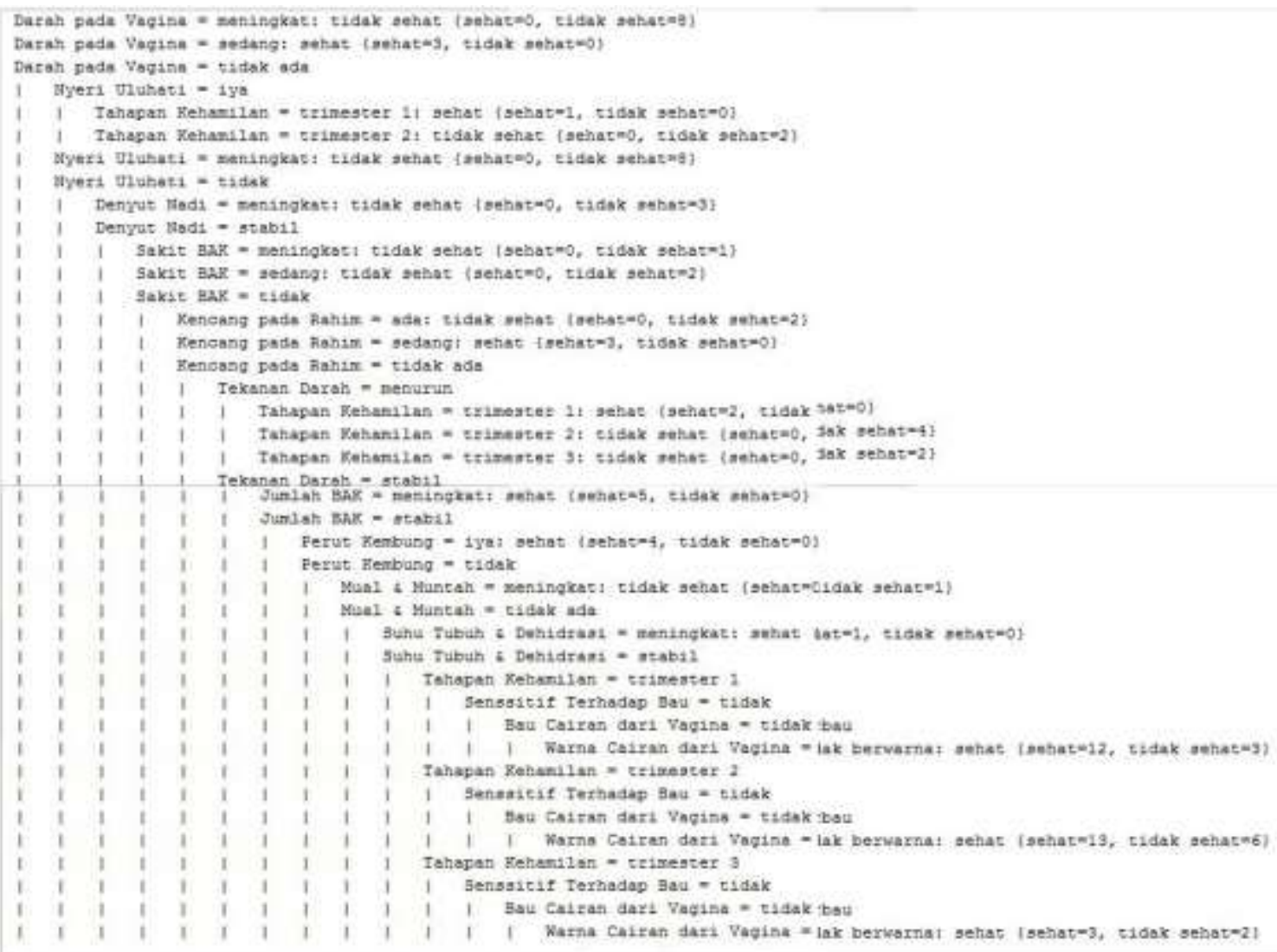

Gambar 4 Description Tree 


\subsection{Hasil Implementasi Menggunakan Perhitungan Manual}

Dalam melakukan perhitungan algoritma ID3 terlebih dahulu kita mencari P+, $\mathrm{P}-$, dan juga entropi total. $\mathrm{P}+$ adalah probabilitas sampel $\mathrm{S}$ yang mempunyai class positif. P-adalah probabilitas sampel $S$ yang mempunyai class negatif. Data yang digunakan adalah data dari puskesmas Sukaraja Sukabumi. Dengan total data yaitu 91 data. Dengan 47 data menunjukan kehamilan ibu dalam keadaan sehat, dan 44 data menunjukan kehamilan ibu dalam keadaan tidak sehat.

Tabel 1 Perhitungan P+, P-, dan Entropi Total

\begin{tabular}{|c|c|c|c|c|}
\hline \multirow{2}{*}{\multicolumn{2}{|c|}{ Jumlah Kasus }} & \multicolumn{2}{|c|}{ Hipotesa } & \multirow{2}{*}{ Entropi Total } \\
\hline & & Sehat & \begin{tabular}{|l|} 
Tidak Sehat \\
\end{tabular} & \\
\hline \multicolumn{2}{|l|}{$47+44$} & $\begin{array}{c}\text { *47 data } \\
\text { kehamilan sehat }\end{array}$ & $\begin{array}{c}\text { *44 data } \\
\text { kehamilan tidak } \\
\text { sehat }\end{array}$ & $-P_{+} \log _{2} P_{+}-P_{-} \log _{2} P_{-}$ \\
\hline \multicolumn{2}{|l|}{91} & 47 & 44 & \multirow{3}{*}{0,999215879} \\
\hline $\mathrm{P}+$ : (Sehat) & $* 47 / 91$ & \multicolumn{2}{|c|}{0,516483516} & \\
\hline P-: (Tidak Sehat) & $* 44 / 91$ & \multicolumn{2}{|c|}{0,483516484} & \\
\hline
\end{tabular}

Sumber: Data hasil olahan

Selanjutnya melakukan perhitungan entropi dan gain dari setiap atribut, yang terdiri dari, tahapan kehamilan, mual dan muntah, perut kembung, nyeri ulu hati, semsitif terhadap bau, darah pada vagina, sakit buang air kecil, jumlah buang air kecil, tekanan darah, denyut nadi, suhu tubuh \& dehirasi, kencang pada rahim, bau cairan dari vagina, dan warna cairan dari vagina. 
Tabel 2 Perhitungan pada Atribut Tahapan Kehamilan

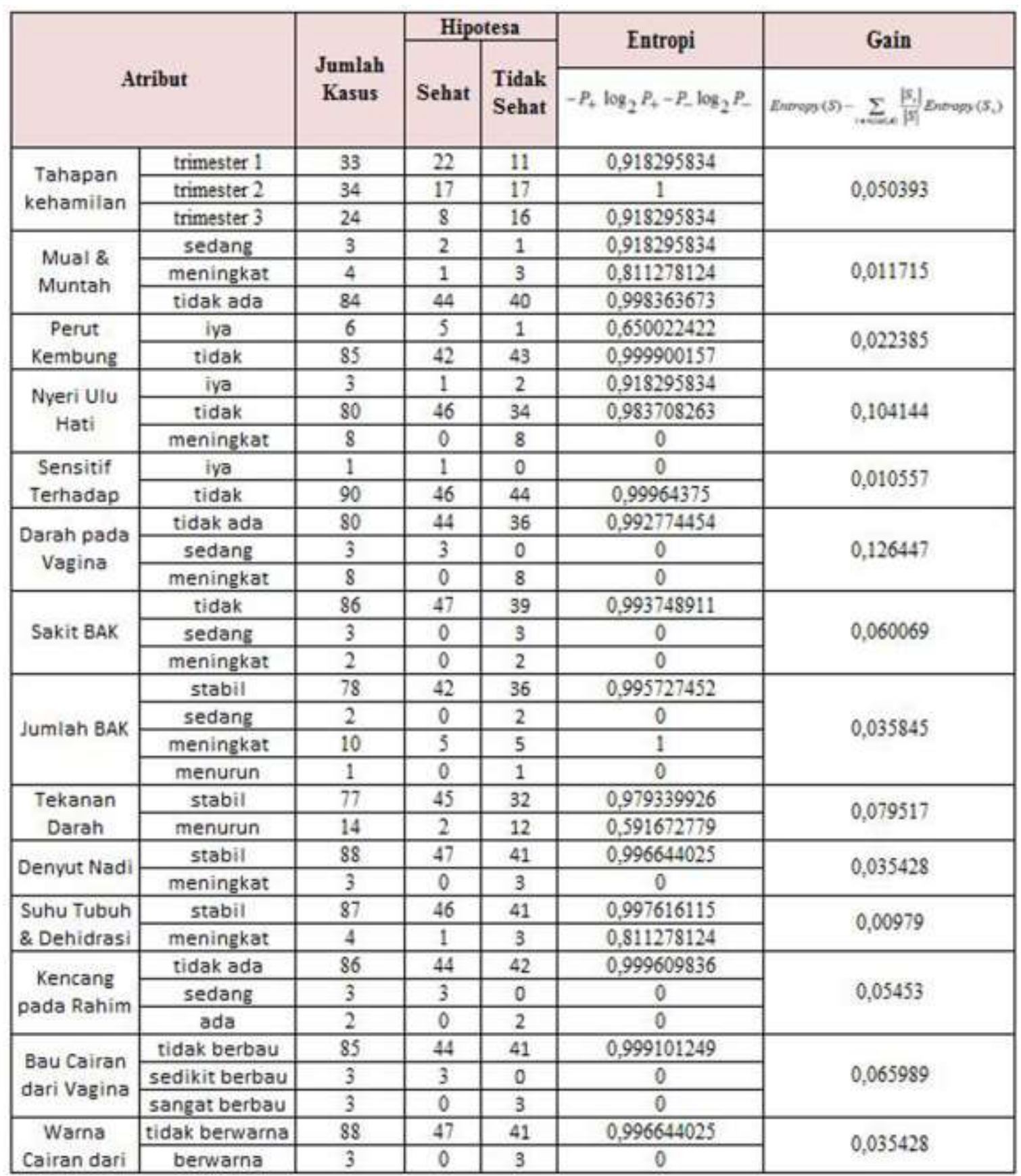

Sumber: Data hasil olahan

\section{SIMPULAN}

Berdasarkan hasil penelitian penerapan algoritma iterative dichotomiser three dalam menentukan kesehatan pada ibu hamil tersebut, dapat diambil kesimpulan bahwa:

a. Proses penerapan metode iterative dichotomiser three (ID3) dalam klasifikasi diagnosa kesehatan kehamilan berdasarkan pada hasil pengujian yang 
dilakukan model klasifikasi dengan menggunakan algoritma iterative dichotomiser three mempunyai nilai optimal akurasi sebesar 80,33\%.

b. Setelah pengolahan data yang diambil dari Puskesmas Sukaraja Sukabumi menggunakan algoritma ID3 dan diolah menggunakan proses data mining, variabel yang paling berpengaruh dalam mendiagnosa kesehatan kehamilan adalah darah pada vagina dengan gain sebesar 0,126447 dan variabel yang paling tidak berpengaruh yaitu variabel suhu tubuh \& dehidrasi dengan gain terkecil 0,00979 . Hal ini terbukti pada metode ID3 yang menyatakan variabel darah pada vagina menempati posisi sebagai root node, dan suhu tubuh dan dehidrasi menempati posisi sebagai internal node terakhir.

\section{DAFTAR PUSTAKA}

[1] D. Hariyanto, "Hubungan Antara Usia Ibu saat Hamil dengan Terjadinya Sindrom Down," 2018.

[2] W. O. P. Lestaria, H. Bahar, and S. Munandar, "Peran Bidan Dan Dukun Dalam Perawatan Kehamilan Ibu Hamil Di Wilayah Pesisir Kecamatan Abeli (Studi Kasus) Kota Kendari 2016," J. Imiah Mhs. Kesehat. Masy., vol. 1, 2016.

[3] N. D. Damayanti, D., Wardani, R. S., \& Indrawati, "STUDI DESKRIPTIF TINGKAT PENGETAHUAN TENTANG KETIDAKNYAMANAN SELAMA KEHAMILAN PADA IBU HAMIL TRIMESTER PERTAMA DI BPM Ny.A PUNDENARUM DEMAK," J. Kebidanan, pp. 74-80.

[4] M. Damayanti and M. Rosdiana, "Dalam Menghadapi Proses Persalinan Di Bpm Ch Mala Palembang," pp. 250-254, 2016.

[5] Y. Elmande and P. Widodo, "Pemilihan Criteria Splitting dalam Algoritma Iterative Dichotomiser 3 (ID3) untuk Penentuan Kualitas Beras: Studi Kasus Pada Perum Bulog Divre Lampung," J. Telemat. MKOM, vol. 4, no. 1, 2012.

[6] M. Safii and K. Akuntansi, "Implementasi Data Mining Dengan Metode Pohon Keputusan Algoritma Id3 Untuk Menentukan Status Mahasiswa,” vol. 2, no. 1, pp. 82-86, 2018.

[7] E. Mayadewi, P., \& Rosely, "Prediksi Nilai Proyek Akhir Mahasiswa Menggunakan," istem Inf. Indones., no. November, pp. 2-3, 2015.

[8] N. R. Shahar and Y. S. Nugroho, "Analisis Faktor-Faktor Penyebab Proses Persalinan Secara Caesar Menggunakan Algoritma Id3 Dengan Metode Decision Tree," 2016.

[9] M. Mirqotussa'adah, M. A. Muslim, E. Sugiharti, B. Prasetiyo, and S. Alimah, "Penerapan Dizcretization dan Teknik Bagging Untuk Meningkatkan Akurasi Klasifikasi Berbasis Ensemble pada Algoritma C4.5 dalam Mendiagnosa Diabetes," Lontar Komput. J. Ilm. Teknol. Inf., vol. 8, no. 2, p. 135, 2017. 
[10] L. P. P. Diani and L. K. P. A. Susilawati, "Pengaruh Dukungan Suami Terhadap Istri Yang Mengalami Kecemasan Pada Kehamilan Trimester Ketiga Di KabupatenGianyar," Univ. Udayana, vol. 1, no. 1, pp. 1-11, 2013. 